\title{
Gentamicin as a selective agent for the isolation of beta haemolytic streptococci
}

\author{
WILLIAM A. BLACK ${ }^{1}$ AND FRANCES VAN BUSKIRK \\ From the Department of Microbiology, St Joseph's Hospital, London, Ontario, Canada
}

SYNOPSIS The isolation of beta haemolytic streptococci was compared using Columbia sheep blood agar with and without gentamicin in a final concentration of 5.5 micrograms per ml. The inclusion of gentamicin gave greatly improved results whenever the isolation of this organism in pure culture was complicated by overgrowth with Gram-negative bacilli or staphylococci.

The isolation of beta haemolytic streptococci from a mixed culture is a recurring problem. Although several selective media containing various inhibitors are already available all of these have their disadvantages. In an attempt to overcome some of the problems, a new medium containing gentamicin was prepared and evaluated in this laboratory.

\section{Materials and Methods}

\section{MEDIUM}

Preliminary trials compared Columbia blood agar base (Oxoid CM331) with Diagnostic Sensitivity Test agar (Oxoid CM261), sheep blood with horse blood in final concentrations ranging from 5 to $10 \%$, and aerobic with anaerobic methods of incubation. Gentamicin was tested in final concentrations ranging from 2 to $8 \mu \mathrm{g} / \mathrm{ml}$.

Complete inhibition of stock cultures of both staphylococci and Gram-negative bacilli, together with optimal colonial morphology and haemolysis of clinical isolates of beta haemolytic streptococci, was given by anaerobic incubation of Columbia blood agar base containing final concentrations of $10 \%$ sheep blood and $5.5 \mu \mathrm{g} / \mathrm{ml}$ of commercial gentamicin. This medium was used throughout the trial.

\section{GENTAMICIN}

Gentamicin powder supplied by the Schering Corporation and containing $53.9 \%$ active base was used initially. This was replaced before the trial by commercial gentamicin (Schering) containing 40 $\mathrm{mg} / \mathrm{ml}$ to obtain a medium that could be prepared easily in any laboratory. Using sterile distilled

1Present address: Dept. of Microbiology, University Hospital, London, Ontario, Canada.

Received for publication 1 December 1972. water, a working dilution of $110 \mu \mathrm{g} / \mathrm{ml}$ was prepared which was stable for at least three months when stored at $4^{\circ} \mathrm{C}$. This was added to the molten sheep blood agar base in a ratio of 1:20 to give a final concentration of $5.5 \mu \mathrm{g} / \mathrm{ml}$.

\section{EVALUATION OF THE TEST MEDIUM}

During a 14-week period in which the laboratory received a total of 10770 specimens, 99 specimeng showing beta haemolytic streptococci, in either purt or mixed culture, on the routine diagnostic plates were re-plated from the Amies transport medium (Bacto-0996) to gentamicin blood agar and a control sheep blood agar plate without gentamicin. The 99 specimens were selected from a total of 195 which contained beta haemolytic streptococci and included all the specimens heavily overgrown by Gramnegative bacilli. The 96 specimens not assessed on gentamicin blood agar were either repeat specimens, pure cultures of beta haemolytic streptococci, or respiratory tract specimens. After overnight anaerobic incubation the plates were examined and the results noted.

STREPTOCOCCAL GROUPING AND TYPING Streptococcal isolates were Lancefield grouped using a modification of the method of Rantz and Randall (1955). Griffith's typing was done at the National Streptococcus Typing Centre, Ottawa.

\section{Results}

An analysis of the specimens containing beta haemolytic streptococci together with the Lancefield grouping of the isolates is shown in table $I$.

The results of the main investigation are detailed in table II. Gentamicin blood agar proved most useful in separating beta haemolytic streptococci 


\begin{tabular}{|c|c|c|c|c|c|c|c|}
\hline \multirow[t]{2}{*}{ Source } & \multirow{2}{*}{$\begin{array}{l}\text { No. of } \\
\text { Specimens }\end{array}$} & \multicolumn{5}{|c|}{ Lancefield Group } & \multirow{2}{*}{$\begin{array}{l}\text { Beta Haemolytic } \\
\text { Streptococcal } \\
\text { Isolates }\end{array}$} \\
\hline & & $A$ & $\boldsymbol{B}$ & $C$ & $\boldsymbol{G}$ & Not $A, B, C, G$ & \\
\hline $\begin{array}{l}\text { Sputum } \\
\text { Nose } \\
\text { Throat } \\
\text { Ear } \\
\text { Wound swab } \\
\text { Vaginal }\end{array}$ & $\begin{array}{r}771 \\
617 \\
820 \\
89 \\
1379 \\
390\end{array}$ & $\begin{array}{r}0 \\
1 \\
29 \\
6 \\
21 \\
2\end{array}$ & $\begin{array}{r}2 \\
2 \\
6 \\
0 \\
9 \\
12\end{array}$ & $\begin{array}{r}0 \\
0 \\
9 \\
1 \\
26 \\
0\end{array}$ & $\begin{array}{r}0 \\
0 \\
7 \\
0 \\
12 \\
2\end{array}$ & $\begin{array}{r}2 \\
3 \\
14 \\
2 \\
18 \\
9\end{array}$ & $\begin{array}{r}4 \\
6 \\
65 \\
9 \\
86 \\
25\end{array}$ \\
\hline Total & 4066 & 59 & 31 & 36 & 21 & 48 & 195 \\
\hline
\end{tabular}

Table I Analysis of beta haemolytic streptococcal isolates by source and Lancefield group

from mixed culture with Gram-negative bacilli and staphylococci. Specimens taken from wound swabs and from the rectal area show beta haemolytic streptococci in pure culture, despite overgrowth of the control plates by Gram-negative bacilli, particularly Proteus. Gentamicin blood agar did not usually yield higher isolation rates of beta haemolytic streptococci in pure culture from upper respiratory tract specimens due to failure to inhibit much of the normal respiratory flora. It did prove valuable when the specimens contained staphylococci or Gramnegative bacilli.

With the exception of seven isolates all beta haemolytic streptococci grew on gentamicin blood agar. Six of the organisms which failed to grow, however, were presumably the same strain of Lance- field group $\mathbf{A}$ as they came from different members of one family and belonged to the same Griffith's type, namely, M23T23.

An additional five strains of beta haemolytic streptococci showed some inhibition of haemolysis or decrease in colonial size.

\section{Discussion}

As shown in table I, and as reported from other areas (British Medical Journal, 1970), streptococcal infection is still common. The provision of a satisfactory medium for the selective isolation of beta haemolytic streptococci is important as streptococci from sites other than the respiratory tract may be nephritogenic (Dillon, 1967) and Lancefield grouping

\begin{tabular}{|c|c|c|c|c|c|c|c|}
\hline \multirow{3}{*}{$\begin{array}{l}\text { Source of } \\
\text { Specimen }\end{array}$} & \multicolumn{2}{|l|}{ Control Blood Agar } & \multicolumn{5}{|c|}{ Gentamicin Blood Agar } \\
\hline & \multirow{2}{*}{\multicolumn{2}{|c|}{$\begin{array}{l}\text { Number of Specimens Showing Beta } \\
\text { Haemolytic Streptococci (BHS) }\end{array}$}} & \multicolumn{3}{|c|}{ Number of Specimens Showing } & \multicolumn{2}{|c|}{ Inhibition of $B H S$} \\
\hline & & & $\begin{array}{l}\text { BHS in } \\
\text { Pure } \\
\text { Culture }\end{array}$ & $\begin{array}{l}\text { BHS with } \\
\text { Gram-negative } \\
\text { Bacilli }\end{array}$ & $\begin{array}{l}\text { BHS with } \\
\text { Normal } \\
\text { Flora }\end{array}$ & Slight & Complete \\
\hline $\begin{array}{l}\text { Wounds (other than } \\
\text { rectal area) }\end{array}$ & $\begin{array}{l}\text { In pure culture } \\
\text { With Gram-negative bacilli } \\
\text { With staphylococci }\end{array}$ & $\begin{array}{l}12 \\
15 \\
10\end{array}$ & $\begin{array}{r}6 \\
15 \\
10\end{array}$ & $\bar{z}$ & E & $\frac{1}{-}$ & - \\
\hline $\begin{array}{l}\text { Rectal area } \\
\text { specimens }\end{array}$ & $\begin{array}{l}\text { In pure culture } \\
\text { With Gram-negative bacilli }\end{array}$ & $\begin{array}{l}1 \\
5\end{array}$ & $\begin{array}{l}1 \\
4\end{array}$ & $\overline{1^{1}}$ & - & $\overline{-}$ & - \\
\hline Sputum & $\begin{array}{l}\text { With Gram-negative bacilli } \\
\text { With staphylococci }\end{array}$ & $\begin{array}{l}1 \\
2\end{array}$ & $\begin{array}{l}1 \\
2\end{array}$ & - & - & - & 二 \\
\hline Throat & $\begin{array}{l}\text { In pure culture } \\
\text { With Gram-negative bacilli } \\
\text { With staphylococci } \\
\text { With normal respiratory flora }\end{array}$ & $\begin{array}{r}5 \\
4 \\
2 \\
22\end{array}$ & $\begin{array}{r}3 \\
4 \\
2 \\
-\end{array}$ & $\begin{array}{l}- \\
-\end{array}$ & $\bar{z}$ & $\frac{2}{-}$ & $\frac{-}{1}$ \\
\hline Nose & $\begin{array}{l}\text { With Gram-negative bacilli } \\
\text { With staphylococci }\end{array}$ & $\begin{array}{l}1 \\
2\end{array}$ & $\begin{array}{l}1 \\
1\end{array}$ & - & - & $\overline{1}$ & - \\
\hline Ear & $\begin{array}{l}\text { In pure culture } \\
\text { With staphylococci }\end{array}$ & $\begin{array}{l}3 \\
4\end{array}$ & $\begin{array}{l}1 \\
4\end{array}$ & - & - & 1 & 1 \\
\hline Vaginal & $\begin{array}{l}\text { In pure culture } \\
\text { With Gram-negative bacilli } \\
\text { With staphylococci } \\
\text { With Gram-negative and normal } \\
\text { vaginal flora }\end{array}$ & $\begin{array}{l}1 \\
5 \\
1 \\
3\end{array}$ & $\begin{array}{r}1 \\
5 \\
1 \\
-\end{array}$ & $\begin{array}{l}- \\
-\end{array}$ & - & $\bar{z}$ & $\bar{z}$ \\
\hline Totals & & 99 & 62 & 1 & 24 & 5 & $7^{2}$ \\
\hline
\end{tabular}

Table II Comparison of gentamicin blood agar and the control plate in the isolation of beta haemolytic streptococci (BHS)

1 Providence.

'Six of these isolates were from the same family and were of the same Griffith's type. 
of streptococcal isolates must not be omitted or delayed because of difficulty in separating streptococci from mixed bacterial cultures.

The relevant literature contains reports of unsatisfactory performance of some constituents of most of the existing selective media. Neomycin (Elston, 1965; Blanchette and Lawrence, 1967), colomycin (Ellner, Stoessel, Drakeford, and Vasi, 1966), sodium azide (Snyder and Lichstein, 1940), or polymyxin (Kidson, 1967) fail to inhibit some strains of Proteus which is the single most troublesome contaminant. Nalidixic acid (Beerens and Tahon-Castel, 1966; Ellner et al, 1966; CloutierLambin and Gauvreau, 1968) fails to inhibit some strains of staphylococci and Pseudomonas. Phenylethanol agar (Bacto 0504), which was formerly used in this laboratory, alters the colonial morphology and haemolysis of streptococcal isolates and permits the survival of Proteus strains which reappear on subculture. Polymyxin, neomycin, and fusidic acid (PNF) medium (Kidson, 1967), in addition to failing to inhibit some swarming Proteus strains, retards the growth of some isolates. This latter medium shares with others which contain multiple inhibitors (Ellner et al, 1966; Cloutier-Lambin and Gauvreau, 1968) the disadvantages of being difficult to prepare and to quality control.

Because of these difficulties, the use of a simple medium containing gentamicin as a single selective agent was considered. No references to this use of gentamicin were found in the literature although reports of the incorporation of this antibiotic in tissue culture media (Rudin, Healey, Phillips, Glump, and Forsyth, 1970) and in selective media for fungi (Dolan, 1972) were noted. After extensive preliminary investigations the final formula for gentamicin blood agar was determined and a trial of the medium instituted.

The results of this trial were satisfactory. Gentamicin blood agar completely inhibited all staphylococci and all Gram-negative bacilli with the exception of a single strain of Providence. Even the optimal concentration of gentamicin did, however, inhibit a small number of streptococci and this would preclude the use of gentamicin blood agar as a sole primary isolation medium. Over the last year in this laboratory, gentamicin blood agar has proved an excellent subculture medium for streptococci in mixed culture. In addition, it has increased the isolation rate of beta haemolytic streptococci by at least $30 \%$ when used as a supplementary primary isolation medium for the examination of material from sites where streptococci may be encountered in mixed culture with Gram-negative bacilli or staphylococci.

We are grateful to Dr J. F. Macdonald of the Schering Corporation for advice and support.

\section{References}

Beerens, H., and Tahon-Castel, M. M. (1966). Milieu à l'acide nalidixique pour l'isolement des streptocoques, $D$. pneumoniae, listeria, erysipelothrix. Ann. Inst. Pasteur, III, 90-93.

Blanchette, L. P., and Lawrence, C. (1967). Group A streptococcus screening with neomycin blood agar. Amer. J. clin. Path., 48, 441-443.

British Medical Journal (1970). Leading article. Streptococcal sepsis. Brit. med.J., 1, 513-514.

Cloutier-Lambin, L., and Gauvreau, L. (1968). Milieux sélectifs à l'acide nalidixique et à l'alcool $\beta$-phényléthylique pour l'isolement de bactéries à gram-positif. Rev. canad. Biol. 27, 29-35.

Dillon, H. C., Jr. (1967). Pyoderma and nephritis. Ann. Rev. Med. 18, 207-218.

Dolan, C. T. (1972). Effect of gentamicin on growth of yeasts, yeast like organisms, and Aspergillus fumigatus. Amer. J. clin. Path. 57, 30-32.

Ellner, P. D., Stoessel, C. J., Drakeford, D. E., and Vasi, F. (1966). A new culture medium for medical bacteriology. Amer. J. clin. Path., 45, 502-504.

Elston, H. R. (1965). Neomycin blood agar for the selective culture of pneumococcus and certain other bacteria. J. Path. Bact., 90, 336-338.

Kidson, A. (1967). A new selective medium for Streptococcus pyogenes and other streptococci. J. med. Lab. Technol., 24, 179-186.

Rantz, L. A., and Randall, E. (1955). Use of autoclaved extracts of haemolytic streptococci for serological grouping. Stanf. med. Bull., 13, 290-291.

Rudin, A., Healey, A., Phillips, C. A., Glump, D. W., and Forsyth, B. R. (1970). Antibacterial activity of gentamicin sulfate in tissue culture. Appl. Microbiol., 20,989-990.

Snyder, M. L., and Lichstein, H. C. (1940). Sodium azide as an inhibiting substance for gram-negative bacteria. J. infect. Dis., 67, 113-115. 